\title{
Crop Load Reduction and Fruit Size Following Multi-step Thinning of 'Empire' Apple
}

\author{
Ed Stover ${ }^{1}$, Mike Fargione, and Richard Risio \\ Department of Horticultural Sciences, NYSAES, Cornell University, Hudson \\ Valley Laboratory, Highland, NY 12528 \\ Xiaoe Yang \\ University of Florida, Indian River Research and Education Center, \\ Ft. Pierce, FL 34945-3138
}

Additional index words. Accel ${ }^{\mathrm{TM}}$, alternate bearing, BA, 6-BA, 6-benzyladenine, biennial bearing, carbaryl, crop load, endothall, fruit size, Malus $\times$ domestica, multi-step thinning, NAA, naphthalene acetic acid, return bloom, Sevin

Abstract. Two years of field experiments were conducted in eastern New York to evaluate the efficacy of a multi-step thinning approach on reducing crop load (no. fruit per $\mathbf{c m}^{2}$ trunk cross-sectional area) and increasing fruit size of 'Empire' apple (Malus Xdomestica Borkh.). Applications of Endothall (ET) at $80 \%$ bloom, NAA + carbaryl (CB) at petal fall $(\mathrm{PF})$, and Accel $^{\mathrm{TM}}+\mathrm{CB}$ at $10 \mathrm{~mm}$ king fruitlet diameter (KFD), alone and in all combinations, were compared to a nonthinned control and to the application of $\mathrm{NAA}+\mathrm{CB}$ at $10 \mathrm{~mm}$ KFD (commercial standard). In both 1996 and 1997, orthogonal contrasts indicated the multi-step treatment significantly increased fruit size, reduced cropload, and reduced yield compared to single applications. Effects on cropload of consecutive treatments were largely predicted by multiplying effects of individual treatments. Although all thinning treatments except for NAA + CB at PF in 1997 significantly reduced cropload, no single treatment thinned sufficiently to ensure good return bloom. Compared to NAA + CB at $10 \mathrm{~mm}$ KFD, multi-step thinning with $\mathrm{NAA}+\mathrm{CB}$ at PF followed by Acce $^{\mathrm{TM}}+\mathrm{CB}$ at 10 mm KFD produced bigger fruits in both years, and resulted in a higher percentage of spurs carrying a single fruit in 1996. When fruit size was evaluated after removing the effect of cropload (cropload adjusted fruit weight), NAA + CB at PF, Accel ${ }^{\mathrm{TM}}+\mathrm{CB}$ at $10 \mathrm{~mm}$, and the two applied sequentially, resulted in greater cropload adjusted fruit weight than the nonthinned control in both years, whereas NAA + CB at $10 \mathrm{~mm}$ did not. Contrast analysis of treatments with and without ET showed no significant effect of including ET on fruit size, though total cropload was reduced at $P=0.10$ and total yield was reduced $(P=0.03$ in 1996 and $P=0.12$ in 1997). No deleterious effects from multi-step treatments have been observed. All thinning treatments significantly increased return bloom in 1996 and 1997 compared to the control with little difference observed between treatments. Chemical names used: naphthalene acetic acid (NAA); 1-naphthyl- $N$-methylcarbamate [carbaryl (CB)]; 6-benzyladenine [BA $\left(\right.$ Accel $\left.^{\mathrm{TM}}\right)$ ]; 7-oxabicyclo $(2,2,1)$ heptane-2,3 dicarboxylic acid [ET (Endothall $\left.{ }^{\mathrm{TM}}\right)$ ]

Postbloom chemical thinning of apple fruit is a standard practice to improve fruit size, increase return bloom, reduce biennial cropping and optimize crop value (Forshey, 1986; Williams and Edgerton, 1981). Since either excessive or inadequate thinning can be costly for apple growers, there is considerable incentive to increase the precision of the thinning process.

NAA, carbaryl (CB), and BA (Accel ${ }^{\mathrm{TM}}$; Valent BioSciences, Libertyville, Ill.) are the most common postbloom chemical thinners in apples, applied either alone or as NAA or BA in combination with $\mathrm{CB}$ (Robinson et al., 1998; Williams and Edgerton, 1981). Maximum thinning is reported when NAA and BA

Received for publication 26 July 2000 . Accepted for publication 22 Feb. 2001.

${ }^{1}$ Current Address: Univ. of Florida, Indian River Research and Education Center, 2199 South Rock Rd., Ft. Pierce, FL 34945-3138. are applied at $\approx 10$-mm king fruitlet diameter (KFD) (Greene, 1993; Leuty, 1973), and this has been a common commercial timing for postbloom thinner application. In our previous studies, we found that $\mathrm{Accel}^{\mathrm{TM}}+\mathrm{CB}$ at $10-\mathrm{mm}$ $\mathrm{KFD}$ and NAA + CB at petal fall (PF) effectively thinned 'Empire' apple, and provided larger cropload adjusted fruit weight than the standard NAA + CB at 10-mm KFD (Stover et al., 2001a).

Blossom thinning was widely used in the western United States before registration was lost for dinitro-o-cresol. An aquatic herbicide, ET (Endothall ${ }^{\mathrm{T} M}$; Elf-Atochem, Philadelphia), was shown to be an effective blossom thinner for apples (Williams et al., 1995) and may become registered for this purpose. Because there are usually several days between bloom, $\mathrm{PF}$, and 10-mm KFD treatments, growers have the opportunity to thin at several stages of fruit development. If likely thinning effectiveness could be estimated, growers could apply sub- sequent treatments for further thinning as necessary. Since thinning response is variable, and both over- and under-thinning can reduce crop value, such a sequential approach to thinning may provide better control of cropping than does reliance on a single thinning treatment. The objective of this study was to evaluate the potential of sequential thinning treatments to reduce crop load, increase fruit size, and enhance return bloom in 'Empire' apple. Three separate thinning regimes (ET at $60 \%$ to $80 \%$ bloom, NAA + CB at PF and $\mathrm{Accel}^{\mathrm{TM}}+\mathrm{CB}$ at $10 \mathrm{~mm}$ ) were tested alone and in all combinations against the typical commercial treatment of NAA $+\mathrm{CB}$ at $10-\mathrm{mm}$ KFD.

\section{Materials and Methods}

Multiple-step thinning experiment. Trials were conducted in 1996 and 1997 in a commercial orchard in eastern New York using 'Empire' trees on M.9/MM.111 rootstock planted in 1991 at $5.5 \times 3.0-\mathrm{m}$ spacing. Productive uniform trees were selected and experiments were established using single-tree experimental units and eight randomized complete blocks each year. Blossom clusters were counted on entire trees and trunk circumference was measured at $25 \mathrm{~cm}$ above the soil level. The experiment was blocked by number of blossom clusters per $\mathrm{cm}^{2}$ trunk cross-sectional area (TCSA). Thinners were applied on the day nearest the indicated phenological stage, when conditions were considered best for chemical thinning: high temperature expected to reach 21 to $24{ }^{\circ} \mathrm{C}$, temperature at application of 18 to $21^{\circ} \mathrm{C}$, slow drying conditions, and no rain expected for at least $6 \mathrm{~h}$. Most applications were made in the early morning when there was no dew on the trees. ET was used as $3.8 \%(\mathrm{w} / \mathrm{w})$ solution; 6-BA was used in the product Accel ${ }^{\mathrm{TM}}$, which has $1.8 \%(\mathrm{w} / \mathrm{w}) 6-\mathrm{BA}$ and $0.18 \%(\mathrm{w} / \mathrm{w}) \mathrm{GA}_{4+7}$; NAA was used in the formulation of Fruit Fix K-Salt 200 ${ }^{\mathrm{TM}}$ (AmVac Chemical Corp, Long Beach, Calif.). CB was used as Sevin XLR $+^{\mathrm{TM}}$ (Rhone-Poulenc, Research Triangle Park, N.C.). The concentration of each chemical thinner used and the time of application for all treatments are shown in Table 1. Chemical thinners were applied at full dilute rate based on tree size $\left(1010 \mathrm{~L} \cdot \mathrm{ha}^{-1}\right)$ using a handgun to simulate airblast treatment in 1996 and using an airblast sprayer in 1997.

Measurements. At commercial harvest, the number and total weight of fruit per tree were determined. Numbers of recent drops were counted and assumed to be of average fruit weight. From these data, the mean fruit weight and cropload (number of fruit $/ \mathrm{cm}^{2} \mathrm{TCSA}$ ) were calculated for each tree. A random sample of 20-25 fruit was also collected from each tree and were evaluated for weight, length, diameter, and seed number. In Spring 1997, 150 spurs on typical branches of each tree treated in 1996 were evaluated to determine the percentage of spurs that flowered. In Spring 1998 , the number of flower clusters was counted on each tree treated in 1997 and return bloom was expressed in bloom clusters $/ \mathrm{cm}^{2}$ TCSA. 
Table 1. Thinning treatments applied to 'Empire' (M.9/MM.111) apple trees in 1996 and 1997.

\begin{tabular}{|c|c|}
\hline Treatment Code & Description \\
\hline Control & Without application of thinners \\
\hline $\mathrm{ET}(\mathrm{B})$ & $\begin{array}{l}\text { Single application of Endothall (ET) at } 80 \% \text { bloom at the dosage } \\
\text { of } 1.33 \text { pint } / 100 \text { gallons }\end{array}$ \\
\hline NAA/CB (PF) & $\begin{array}{l}\text { Single application of NAA }(7.5 \mathrm{ppm}) \text { in combination with } \\
\text { carbaryl }(0.5 \mathrm{lb} \text { a.i } / 100 \mathrm{gal}) \text { at petal fall }\end{array}$ \\
\hline NAA/CB $(10 \mathrm{~mm})$ & $\begin{array}{l}\text { Single application of NAA }(7.5 \mathrm{ppm}) \text { in combination with } \\
\text { carbaryl }(0.5 \mathrm{lb} \text { a.i } / 100 \mathrm{gal}) \text { at } 10 \mathrm{~mm} \text { king fruitlet diameter (KFD) }\end{array}$ \\
\hline $\mathrm{Accel}^{\mathrm{TM}} / \mathrm{CB}(10 \mathrm{~mm})$ & $\begin{array}{l}\text { Single application of } \mathrm{Accel}^{\mathrm{TM}}(75 \mathrm{ppm}) \text { in combination with car } \\
\text { baryl }(0.5 \mathrm{lb} \text { a.i } / 100 \mathrm{gal}) \text { at } 10 \mathrm{~mm} \mathrm{KFD}\end{array}$ \\
\hline $\mathrm{ET}(\mathrm{B})+\mathrm{NAA} / \mathrm{CB}(\mathrm{PF})$ & $\begin{array}{l}\text { Multi-step application of ET }(1.33 \mathrm{pint} / 100 \mathrm{gal}) \text { at } 80 \% \text { bloom } \\
\text { followed by NAA }(7.5 \mathrm{ppm})+\text { carbaryl }(0.5 \mathrm{lb} \text { a.i } / 100 \mathrm{gal}) \text { at } \\
\text { petal fall }\end{array}$ \\
\hline $\mathrm{ET}(\mathrm{B})+\mathrm{Accel}^{\mathrm{TM}} / \mathrm{CB}(10 \mathrm{~mm})$ & $\begin{array}{l}\text { Multi-step application of ET }(1.33 \mathrm{pint} / 100 \mathrm{gal}) \text { at } 80 \% \text { bloom } \\
\text { followed by } \operatorname{Accel}^{\mathrm{TM}}(75 \mathrm{ppm})+\text { carbaryl }(0.5 \mathrm{lb} \text { a.i } / 100 \mathrm{gal}) \text { at } \\
10 \mathrm{~mm} \mathrm{KFD}\end{array}$ \\
\hline $\begin{array}{l}\mathrm{NAA} / \mathrm{CB}(\mathrm{PF})+\mathrm{Accel}^{\mathrm{TM}} / \mathrm{CB} \\
\quad(10 \mathrm{~mm})\end{array}$ & $\begin{array}{l}\text { Multi-step application of NAA }(7.5 \mathrm{ppm})+\text { carbaryl }(0.5 \mathrm{lb} \text { a.i/ } \\
100 \mathrm{gal}) \text { at petal fall followed by } \operatorname{Accel}^{\mathrm{TM}}(75 \mathrm{ppm})+\text { carbaryl } \\
(0.5 \mathrm{lb} \text { a.i } 100 \mathrm{gal}) \text { at } 10 \mathrm{~mm} \text { KFD }\end{array}$ \\
\hline $\begin{array}{l}\mathrm{ET}(\mathrm{B})+\mathrm{NAA} / \mathrm{CB}(\mathrm{PF})+\mathrm{Accel}^{\mathrm{TM}} \\
\quad / \mathrm{CB}(10 \mathrm{~mm})\end{array}$ & $\begin{array}{l}\text { Multi-step application of ET }(1.33 \mathrm{pint} / 100 \mathrm{gal}) \text { at } 80 \% \text { bloom, } \\
\text { followed by NAA }(7.5 \mathrm{ppm})+\operatorname{carbaryl}(0.5 \mathrm{lba} \text { a.i } / 100 \mathrm{gal}) \text { at petal } \\
\text { fall, followed by } \operatorname{Accel}^{\mathrm{TM}}(75 \mathrm{ppm})+\text { carbaryl }(0.5 \mathrm{lb} \text { a.i } / 100 \mathrm{gal}) \\
\text { at } 10 \mathrm{~mm} \text { KFD }\end{array}$ \\
\hline
\end{tabular}

Observations on fruitlets prior to thinner application. Fruitlets were examined for discoloration indicative of early abscission and evidence of seed abortion prior to each successive chemical thinner application. Observations were made both in the field while fruitlets were attached, and in the lab using light microscopy.

Calculation of the adjusted fruit size. Fruit size increase relative to cropload reduction is an important feature when comparing thinning treatments, since larger economic returns are likely when relatively small cropload reductions result in large increases in fruit size. To examine this aspect, cropload adjusted fruit weights were calculated for each tree using SAS ProcGLM (Cary, N.C.) by regressing cropload vs. mean fruit size for all trees in each year, generating the residual value for variation of each tree from the pooled correlation, and adding the residual for each tree to the overall mean fruit weight (Stover et al., 2001a).
All data were subjected to analysis of variance (ANOVA) using ProcGLM (SAS Institute, Cary, N.C.) and means were separated using Duncan's multiple range test (DMRT). Planned contrasts were also conducted using ProcGLM to compare groups of treatments.

\section{Results}

Effect on crop load. The crop load of the nonthinned controls was relatively high, at 14.9 fruit $/ \mathrm{cm}^{2}$ TCSA in 1996 and 16.5 in 1997. All single and multi-step thinning treatments reduced crop load compared to the nonthinned control in 1996 (Table 2) and all except for $\mathrm{NAA}+\mathrm{CB}$ at PF in 1997 (Table 3). Contrast analysis indicated that multi-step treatments reduced crop load $(P \leq 0.006)$ compared to single treatments. Comparison of NAA $+\mathrm{CB}$ at $\mathrm{PF}$ or $\mathrm{Accel}^{\mathrm{TM}}+\mathrm{CB}$ at $10 \mathrm{~mm}$ applied as single treatments with the multi-step application of NAA $+\mathrm{CB}$ at PF followed by $\mathrm{Accel}^{\mathrm{TM}}$
$+\mathrm{CB}$ at $10 \mathrm{~mm}$ showed that the multi-step treatment reduced crop load in both $1996(P=$ $0.012)$ and $1997(P=0.027)$ (Tables 2 and 3). Although most thinning treatments resulted in statistically similar croploads, the lowest crop load (10.1 fruit $/ \mathrm{cm}^{2}$ TCA) in 1997 and the second lowest crop load ( 7.7 fruit $/ \mathrm{cm}^{2}$ TCA) in 1996 were obtained with the multi-step application of NAA + CB at PF and Accel $^{\mathrm{TM}}+$ $\mathrm{CB}$ at $10-\mathrm{mm}$ KFD. Similarly, the multi-step application of ET at $80 \%$ bloom, NAA + CB at $\mathrm{PF}$ and $\mathrm{Accel}^{\mathrm{TM}}+\mathrm{CB}$ at 10-mm KFD resulted in the lowest crop load in 1996 (7.2 fruit $/ \mathrm{cm}^{2}$ TCA) and the second lowest crop load in 1997 (10.8 fruit $/ \mathrm{cm}^{2}$ TCA). Application of ET alone at $80 \%$ bloom reduced crop load in both years, but DMRT indicated no crop load effect from including ET with other treatments except for $\mathrm{NAA}+\mathrm{CB}$ at PF in 1996 (Table 2). Assessment of percent cropload reduction relative to controls indicates that most multi-step treatments gave thinning similar to that expected by multiplying the reduction from each thinning treatment alone. For example in 1996, $\mathrm{NAA}+\mathrm{CB}$ at PF gave $0.70 \times$ control cropload and $\mathrm{Accel}^{\mathrm{TM}}+\mathrm{CB}$ gave $0.67 \times$ control cropload while the sequential use of these treatments gave $0.52 \times$ control cropload which is $10 \%$ more than the 0.47 predicted by multiplying the two individual treatment effects. All multistep treatments in each year gave results within $20 \%$ of that predicted by multiplying effects of individual treatments except for the three-step treatment in 1997 that resulted in 36\% higher cropload than predicted.

Effect on fruit size. Fruit size of the nonthinned controls was relatively high for such high crop loads (unpublished data), $140.4 \mathrm{~g} /$ fruit and $136.3 \mathrm{~g} /$ fruit in 1996 and 1997, respectively. Fruit size was increased by all the treatments in both years except for ET application at $80 \%$ bloom in 1997 (Tables 2 and 3). In both 1996 and 1997, contrast analyses between multi-step thinning and single treatments showed that the multi-step treatments increased fruit size. In both years, the largest

Table 2. Effect of thinning treatments on crop load, fruit size, and return bloom of 'Empire' apple trees (Clintondale, N.Y. 1996).

\begin{tabular}{|c|c|c|c|c|c|c|c|}
\hline Treatment & $\begin{array}{c}\text { Crop load } \\
\text { (fruit/cm }{ }^{2} \\
\text { TCSA }^{z} \text { ) }\end{array}$ & $\begin{array}{c}\text { Fruit } \\
\text { size } \\
\text { (g/fruit) }\end{array}$ & $\begin{array}{l}\text { CAFW }^{y} \\
\text { (g/fruit) }\end{array}$ & $\begin{array}{c}\text { Return } \\
\text { bloom } \\
(\%)\end{array}$ & $\begin{array}{c}\begin{array}{c}\text { Fruit yield } \\
\left(\mathrm{kg} / \mathrm{cm}^{2}\right.\end{array} \\
\text { TCSA })\end{array}$ & $\begin{array}{c}\text { Spurs with } \\
\text { single fruit } \\
(\%)\end{array}$ & $\begin{array}{c}\text { Seed } \\
\text { number } \\
\text { (Seed/fruit) }\end{array}$ \\
\hline Control & $14.9 \mathrm{a}^{\mathrm{x}}$ & $140 \mathrm{~d}$ & $160 \mathrm{~b}$ & $66.0 \mathrm{~b}$ & $2.1 \mathrm{a}$ & $75 \mathrm{ab}$ & $5.1 \mathrm{a}$ \\
\hline $\mathrm{ET}(\mathrm{B})$ & $12.9 \mathrm{~b}$ & $156 \mathrm{c}$ & $167 \mathrm{ab}$ & $82.4 \mathrm{a}$ & $2.0 \mathrm{ab}$ & $71 \mathrm{ab}$ & $5.1 \mathrm{a}$ \\
\hline NAA/CB (PF) & $10.5 \mathrm{c}$ & $173 \mathrm{ab}$ & $175 \mathrm{a}$ & $82.8 \mathrm{a}$ & $1.8 \mathrm{a}-\mathrm{c}$ & $65 \mathrm{~b}$ & $5.4 \mathrm{a}$ \\
\hline $\mathrm{NAA} / \mathrm{CB}(10 \mathrm{~mm})$ & $9.7 \mathrm{~cd}$ & $166 \mathrm{cb}$ & $164 \mathrm{ab}$ & $79.5 \mathrm{a}$ & $1.6 \mathrm{~cd}$ & $68 \mathrm{~b}$ & $5.4 \mathrm{a}$ \\
\hline $\operatorname{Accel}^{\mathrm{TM}} / \mathrm{CB}(10 \mathrm{~mm})$ & $9.9 \mathrm{~cd}$ & $176 \mathrm{ab}$ & $175 \mathrm{a}$ & $88.0 \mathrm{a}$ & $1.7 \mathrm{~b}-\mathrm{d}$ & $78 \mathrm{ab}$ & $5.1 \mathrm{a}$ \\
\hline $\mathrm{ET}(\mathrm{B})+\mathrm{NAA} / \mathrm{CB}(\mathrm{PF})$ & $8.2 \mathrm{~d}$ & $174 \mathrm{ab}$ & $167 \mathrm{ab}$ & $84.6 \mathrm{a}$ & $1.4 \mathrm{~d}$ & $78 \mathrm{ab}$ & $4.8 \mathrm{a}$ \\
\hline $\mathrm{ET}(\mathrm{B})+\mathrm{Accel}^{\mathrm{TM}} / \mathrm{CB}(10 \mathrm{~mm})$ & $9.2 \mathrm{~cd}$ & $177 \mathrm{ab}$ & $174 \mathrm{a}$ & $89.8 \mathrm{a}$ & $1.6 \mathrm{~cd}$ & $72 \mathrm{ab}$ & $4.9 \mathrm{a}$ \\
\hline $\mathrm{NAA} / \mathrm{CB}(\mathrm{PF})+\operatorname{Accel}^{\mathrm{TM}} / \mathrm{CB}(10 \mathrm{~mm})$ & $7.7 \mathrm{~d}$ & $183 \mathrm{a}$ & $174 \mathrm{a}$ & $88.6 \mathrm{a}$ & $1.4 \mathrm{~d}$ & $84 \mathrm{a}$ & $5.1 \mathrm{a}$ \\
\hline $\mathrm{ET}(\mathrm{B})+\mathrm{NAA} / \mathrm{CB}(\mathrm{PF})+\mathrm{Accel}^{\mathrm{TM}} / \mathrm{CB}(10 \mathrm{~mm})$ & $7.2 \mathrm{~d}$ & $181 \mathrm{a}$ & $169 \mathrm{ab}$ & $86.4 \mathrm{a}$ & $1.4 \mathrm{~d}$ & $74 \mathrm{ab}$ & $4.9 \mathrm{a}$ \\
\hline & \multicolumn{7}{|c|}{ Contrasts $(P>F)$} \\
\hline All treatments vs. control & 0.0001 & 0.0001 & 0.0099 & 0.0001 & 0.0001 & 0.5619 & 0.9008 \\
\hline Multi-step thinning vs. single step thinning & 0.0001 & 0.0003 & 0.8004 & 0.1183 & 0.0001 & 0.0318 & 0.0403 \\
\hline ET included in thinning vs. thinning without ET & 0.0915 & 0.7492 & 0.1389 & 0.9796 & 0.0259 & 0.8552 & 0.0287 \\
\hline NAA/CB $10 \mathrm{~mm}$ vs. control & 0.0001 & 0.0001 & 0.4097 & 0.0067 & 0.0027 & 0.1769 & 0.2047 \\
\hline NAA/CB $10 \mathrm{~mm}$ vs. NAA/CB PF and/or $\mathrm{Accel}^{\mathrm{TM}} / \mathrm{CB}$ no ET & 0.5200 & 0.0730 & 0.0289 & 0.0685 & 0.8749 & 0.1380 & 0.2682 \\
\hline NAA/CB PF vs. NAA/CB PF and $\mathrm{Accel}^{\mathrm{TM}} / \mathrm{CB}+/-\mathrm{ET}$ & 0.0064 & 0.1705 & 0.5669 & 0.4376 & 0.0087 & 0.0079 & 0.1116 \\
\hline NAA/CB PF or Accel ${ }^{\mathrm{TM}} / \mathrm{CB}$ vs. together no ET & 0.0118 & 0.1050 & 0.8782 & 0.5480 & 0.0199 & 0.0181 & 0.6592 \\
\hline NAA/CB PF and/or Accel ${ }^{\mathrm{TM}} \mathrm{CB}$ (no ET) vs. control & 0.0001 & 0.0001 & 0.0015 & 0.0001 & 0.0006 & 0.8276 & 0.6325 \\
\hline
\end{tabular}

${ }^{\mathrm{z}} \mathrm{TCSA}=$ trunk cross sectional area

${ }^{y} \mathrm{CAFW}=$ cropload adjusted fruit weight

${ }^{x}$ Within a column, means followed by the same letter are not significantly different at $P<0.05$ using Duncan's multiple range test. 
fruit size was observed for the treatment of $\mathrm{NAA}+\mathrm{CB}$ application at PF followed by the application of Accel $^{\mathrm{TM}}+\mathrm{CB}$ at 10-mm KFD (Tables 2 and 3), which also had among the greatest cropload reductions. In 1996, an increase in cropload adjusted fruit weight was observed in contrast analyses for all treatments vs. control as well as NAA + $\mathrm{CB}$ application at $\mathrm{PF}$ or $\mathrm{Accel}^{\mathrm{TM}}+\mathrm{CB}$ application at $10 \mathrm{~mm} \mathrm{KFD}$ or the two together vs. either control or NAA + CB at $10 \mathrm{~mm}$ (Table 2). In 1997, contrast of NAA + CB at PF, Accel ${ }^{\mathrm{TM}}+$ $\mathrm{CB}$ application at $10-\mathrm{mm}$ KFD or the two together vs. control had a $P$ value of 0.0316 , but the contrast of these treatments vs. NAA + $\mathrm{CB}$ at $10 \mathrm{~mm}$ had a $P$ value $=0.195$. DMRT indicated that the multi-step application of $\mathrm{NAA}+\mathrm{CB}$ at PF followed by Accel ${ }^{\mathrm{TM}}+\mathrm{CB}$ at 10-mm KFD produced greater actual fruit size than the commercial standard thinning program (NAA + CB at $10 \mathrm{~mm}$ ) in both 1996 and 1997 (Tables 2 and 3).

Effect on return bloom. The return bloom of the nonthinned controls was quite good, being $66 \%$ in 1996 and 7.40 flower clusters $/ \mathrm{cm}^{2}$ TCSA in 1997 (Table 2 and 3). Contrast analyses indicated greater return bloom for all thinning treatments vs. nonthinned controls in 1996 and 1997 (Table 2 and 3). There were no differences in return bloom between the multistep and single application treatments. Use of ET alone or in multi-step treatments had no influence on return bloom in either year.

Effect on fruit yield. In 1996, fruit yield was reduced by all thinning treatments, except for the two single application treatments of NAA $+\mathrm{CB}$ at PF and ET at bloom. Whereas in 1997, fruit yield was reduced only by all the multistep treatments as compared with the control (Tables 2 and 3). Contrast analysis between multi-step and single treatments showed that the multi-step treatments resulted in greater fruit yield reductions in both years. Contrasting treatments with ET vs. those without ET indicated that ET alone or in multi-step treatments reduced fruit yield in $1996(P=0.026$,
Table 2) and to a lesser extent in 1997 $(P=0.116$, Table 3$)$.

Other effects. In 1996, multi-step thinning treatments increased the proportion of spurs with single fruit and reduced seed number per fruit compared with the single application treatments (Table 2). Contrast analysis between the application of NAA $+\mathrm{CB}$ at PF or $\mathrm{Accel}^{\mathrm{TM}}+\mathrm{CB}$ at $10 \mathrm{~mm}$ alone and the multistep application of NAA + CB at PF plus Accel $^{\mathrm{TM}}+\mathrm{CB}$ at $10 \mathrm{~mm}$ revealed that the multistep treatment produced a greater percentage of spurs with one fruit in 1996 only. Including ET in the treatments had no effect on the percentage of spurs with single fruit but did decrease the seed number per fruit (Table 2).

\section{Discussion}

Multi-step thinning showed considerable potential in this study, resulting in significantly lower crop loads and greater fruit size than single treatments according to contrast analysis. Indeed, treatments including NAA + $\mathrm{CB}$ at $\mathrm{PF}$ followed by $\mathrm{Accel}^{\mathrm{TM}}+\mathrm{CB}$ at $10 \mathrm{~mm}$ KFD produced the highest crop load reduction and fruit size increase in both 1996 and 1997.

ET alone reduced crop load relative to the controls when applied at $80 \%$ bloom in both years and enhanced fruit size in 1996, but did not thin adequately in either year (Table 2 and $3)$. Including ET in a multi-step thinning strategy reduced crop load $(P=0.09)$ and fruit yield in 1996 but did not increase fruit size and reduced the seed number per fruit; while in 1997, this contrast indicated a modest probability that including ET reduced fruit yield $(P=0.1156)$. Based on results from these two years, there may appear to be little reason for considering use of ET in thinning 'Empire' in the northeastern U.S. However, in some years it appears that apple trees do not respond to fruitlet thinners, and the very different thinning mechanism of blossom thinners, such as ET, may provide a useful degree of thinning when other thinners do not work. It may be advisable for growers to consider the relative advantages of achieving some thinning with ET when unpredictable poor-thinning conditions arise, vs. the disadvantages and expense of using ET when fruitlet thinners are effective. It should also be noted that ET sometimes causes some damage to spur leaves (data not shown).

There are two major influences of thinners on fruit size, one being the reduction in crop load that indirectly affects fruit size by reducing interfruit competition and the other being the direct stimulation of fruit growth (McLaughlin and Greene, 1984; Westwood, 1967; Wismer et al., 1995). As in a previous study (Stover et al., 2001a), both NAA + CB at $\mathrm{PF}$ and $\mathrm{Accel}^{\mathrm{TM}}+\mathrm{CB}$ at $10-\mathrm{mm}$ KFD produced cropload adjusted fruit weight larger than the nonthinned controls in 1996 using DMRT (Table 2), whereas the commercial standard of $\mathrm{NAA}+\mathrm{CB}$ at $10-\mathrm{mm}$ KFD was not significantly different from any of the treatments. A contrast between NAA $+\mathrm{CB}$ at $\mathrm{PF}$ and/or $\mathrm{Accel}^{\mathrm{TM}}+\mathrm{CB}$ at $10 \mathrm{~mm} \mathrm{KFD}$ vs. the commercial standard showed greater cropload adjusted fruit weight than the commercial standard in 1996 ( $P=0.0289)$ but the probability of difference was only 0.1952 in 1997 . BA has been reported to enhance fruit growth beyond the direct affect of thinning (Elfving and Cline; 1993; Greene et al., 1992), which has been attributed to increased cell division (Greene et al., 1990; Wismer et al., 1995). Robinson and Lakso (1991) found that early application of NAA suppressed fruit growth less than when applied at $10 \mathrm{~mm}$ KFD. While the basis of cropload adjusted fruit weight enhancement by NAA + CB at PF is unknown, data from a previous study (Stover et al., 2001a) suggested that thinning to fewer fruit per spur and avoiding negative NAA effects on fruitlet growth may be sufficient to enhance cropload adjusted fruit weight through reduced interfruit competition. However, in 1996 we found increased cropload adjusted fruit weight by $\mathrm{NAA}+\mathrm{CB}$ at PF without any increase in the

Table 3. Effect of thinning treatments on crop load, fruit size, and return bloom of 'Empire' apple trees (Clintondale, N.Y. 1997).

\begin{tabular}{|c|c|c|c|c|c|c|}
\hline Treatment & $\begin{array}{c}\text { Crop load } \\
\text { (fruit/cm } \\
\text { TCSA }^{z} \text { ) } \\
\end{array}$ & $\begin{array}{c}\text { Fruit } \\
\text { size } \\
\text { (g/fruit) }\end{array}$ & $\begin{array}{l}\text { CAFW }^{y} \\
\text { (g/fruit) }\end{array}$ & $\begin{array}{c}\text { Return bloom } \\
\text { (flower/cm } \\
\text { TCSA }^{y} \text { ) } \\
\end{array}$ & $\begin{array}{c}\text { Fruit yield } \\
\left(\mathrm{kg} \cdot \mathrm{cm}^{-2}\right. \\
\text { TCSA })\end{array}$ & $\begin{array}{c}\text { Spurs with } \\
\text { single fruit } \\
(\%)\end{array}$ \\
\hline Control & $16.5 \mathrm{a}^{\mathrm{x}}$ & $136 \mathrm{~d}$ & $147 \mathrm{ab}$ & $7.4 \mathrm{~b}$ & $2.2 \mathrm{a}$ & $85 \mathrm{a}$ \\
\hline ET (B) & $12.8 \mathrm{~b}$ & $143 \mathrm{~cd}$ & $144 \mathrm{~b}$ & $10.5 \mathrm{ab}$ & $1.8 \mathrm{ab}$ & $85 \mathrm{a}$ \\
\hline NAA/CB (PF) & $13.5 \mathrm{ab}$ & $154 \mathrm{a}-\mathrm{c}$ & $157 \mathrm{a}$ & $10.9 \mathrm{ab}$ & $2.1 \mathrm{ab}$ & $89 a$ \\
\hline NAA/CB (10 mm) & $12.7 \mathrm{~b}$ & $150 \mathrm{bc}$ & $151 \mathrm{ab}$ & $10.6 \mathrm{ab}$ & $1.9 \mathrm{ab}$ & $91 \mathrm{a}$ \\
\hline $\mathrm{Accel}^{\mathrm{TM}} / \mathrm{CB}(10 \mathrm{~mm})$ & $12.4 \mathrm{~b}$ & $153 \mathrm{a}-\mathrm{c}$ & $153 \mathrm{ab}$ & $11.2 \mathrm{ab}$ & $1.9 \mathrm{ab}$ & $89 a$ \\
\hline $\mathrm{ET}(\mathrm{B})+\mathrm{NAA} / \mathrm{CB}(\mathrm{PF})$ & $11.5 \mathrm{~b}$ & $152 \mathrm{a}-\mathrm{c}$ & $150 a b$ & $13.0 \mathrm{a}$ & $1.8 \mathrm{~b}$ & $88 \mathrm{a}$ \\
\hline $\mathrm{ET}(\mathrm{B})+\mathrm{Accel}^{\mathrm{TM}} / \mathrm{CB}(10 \mathrm{~mm})$ & $10.8 \mathrm{~b}$ & $155 \mathrm{a}-\mathrm{c}$ & $151 \mathrm{ab}$ & $11.5 \mathrm{ab}$ & $1.6 \mathrm{~b}$ & $89 a$ \\
\hline $\mathrm{NAA} / \mathrm{CB}(\mathrm{PF})+\mathrm{Accel}^{\mathrm{TM}} / \mathrm{CB}(10 \mathrm{~mm})$ & $10.1 \mathrm{~b}$ & 164 a & $158 \mathrm{a}$ & $10.0 \mathrm{ab}$ & $1.6 \mathrm{~b}$ & $88 \mathrm{a}$ \\
\hline $\mathrm{ET}(\mathrm{B})+\mathrm{NAA} / \mathrm{CB}(\mathrm{PF})+\mathrm{Accel}^{\mathrm{TM}} / \mathrm{CB}(10 \mathrm{~mm})$ & $10.8 \mathrm{~b}$ & $159 \mathrm{ab}$ & $155 \mathrm{ab}$ & $10.3 \mathrm{ab}$ & $1.7 \mathrm{~b}$ & $92 \mathrm{a}$ \\
\hline & \multicolumn{6}{|c|}{ Contrasts $(P>F)$} \\
\hline All treatments vs. control & 0.0001 & 0.0002 & 0.1525 & 0.0153 & 0.0037 & 0.1269 \\
\hline Multi-step thinning vs. single step thinning & 0.0056 & 0.0087 & 0.3409 & 0.6656 & 0.0170 & 0.6413 \\
\hline ET included in thinning vs. thinning without ET & 0.2070 & 0.7872 & 0.2076 & 0.4154 & 0.1156 & 0.7927 \\
\hline NAA/CB 10 mm vs. control & 0.0125 & 0.0234 & 0.4649 & 0.0977 & 0.0769 & 0.0826 \\
\hline NAA/CB $10 \mathrm{~mm}$ vs. NAA/CB PF and/or Accel $^{\mathrm{TM}} / \mathrm{CB}$ no ET & 0.5719 & 0.1366 & 0.1952 & 0.9639 & 0.8880 & 0.4960 \\
\hline NAA/CB PF vs. NAA/CB PF and $\mathrm{Accel}^{\mathrm{TM}} / \mathrm{CB}+/-\mathrm{ET}$ & 0.0191 & 0.1375 & 0.9272 & 0.6678 & 0.0179 & 0.7802 \\
\hline NAA/CB PF or $\mathrm{Accel}^{\mathrm{TM}} / \mathrm{CB}$ vs. together no ET & 0.0271 & 0.0385 & 0.4690 & 0.5344 & 0.0492 & 0.7696 \\
\hline NAA/CB PF and/or Accel ${ }^{\mathrm{TM}} / \mathrm{CB}$ vs. control & 0.0005 & 0.0001 & 0.0316 & 0.0399 & 0.0227 & 0.1433 \\
\hline
\end{tabular}

${ }^{\mathrm{z}} \mathrm{TCSA}=$ trunk cross-sectional area

${ }^{\mathrm{y}} \mathrm{CAFW}=$ cropload adjusted fruit size

${ }^{x}$ Within a column, means followed by the same letter are not significantly different at $P<0.05$ using Duncan's multiple range test. 
proportion of spurs carrying single fruit. The multi-step application of NAA $+\mathrm{CB}$ at PF plus $\mathrm{Accel}^{\mathrm{TM}}+\mathrm{CB}$ at $10 \mathrm{~mm}$ resulted in similar cropload adjusted fruit weight as the same two treatments used alone, indicating that the beneficial effects on fruit growth were not compromised by combined application. Increased cropload adjusted fruit weight relative to the controls in both years was observed only with $\mathrm{NAA}+\mathrm{CB}$ at PF and/or Accel ${ }^{\mathrm{TM}}+\mathrm{CB}$ at $10 \mathrm{~mm}$ (contrasts in Tables $2 \& 3$ ). The fact that cropload adjusted fruit weight was unaffected by multi-step vs. single treatment, indicates that the reduction in yield observed with multistep treatments was the result of greater thinning rather than a detrimental affect on tree or fruit health from multiple chemical applications.

Thinning treatments increased return bloom by $24.8 \%$ to $36.1 \%$ in 1996 and $36.4 \%$ to $75.5 \%$ in 1997 , but little difference was noted between treatments. In 1996, the multi-step thinning treatments produced a higher proportion of spurs with single fruit than the single treatments, whereas the combined application of NAA $+\mathrm{CB}$ at PF followed by $\mathrm{Accel}^{\mathrm{TM}}+\mathrm{CB}$ at $10 \mathrm{~mm}$ had a higher proportion of single fruit spurs than NAA + CB at $10 \mathrm{~mm}$ (commercial standard) (Table 2). It should be noted that the nonthinned controls had an unusually high percentage of spurs with only one fruit $(75 \%$ in 1996 and 85\% in 1997), which probably contributed to relatively large fruit size and return bloom, and reduced differences observed among the thinning treatments.

Chemical thinners are typically applied at $\approx 10$-mm KFD in the eastern United States to permit adjustment of thinner rates according to initial fruit set. However, the importance of good fruit size without excessive crop reduction, and the frequent occurrence of poor thinning weather during early fruit development, suggest that apple producers should thin earlier with cultivars such as 'Empire' that are prone to overproduction and small fruit size. Our results showed that multi-step applications of NAA + CB at PF followed by Accel $^{\mathrm{TM}}$ $+\mathrm{CB}$ at 10-mm KFD increased both thinning and fruit size in 'Empire' apples without deleterious effects. Initial thinning with NAA + $\mathrm{CB}$ at $\mathrm{PF}$ offers the potential for assessing likely initial thinning and then adjusting or avoiding subsequent thinning. Unfortunately, in these two years of trials, we could not effectively evaluate the response to the PF thinner prior to application at 10-mm KFD (data not shown). However, effectiveness of
ET thinning could be observed prior to PF. The inability to assess thinner effectiveness prior to treatment greatly weakens the potential value of this approach, and it would be simpler for a grower to use a higher thinner rate at a single timing for greater cropload reduction and fruit size. Further effort should be directed at early assessment of fruitlets likely to abscise, or perhaps environmental and orchard factors could be used to model likely effectiveness of thinners, so that growers could predict initial thinning response and adjust subsequent thinning applications.

Consistent enhancement of fruit size, with high yields and inducement of good return bloom, all contribute to high cumulative crop value, which is the most important consideration in evaluating a chemical thinning program. Contrast analysis from our two years of field trials showed that multi-step thinning treatments significantly reduced crop load and increased fruit size compared to single applications but fruit yield was also reduced (Table 2 and 3). Because fruit size was so large in nonthinned trees, the calculated crop value in the year of treatment was increased by few thinning treatments, with $\mathrm{NAA}+\mathrm{CB}$ at $\mathrm{PF}$ providing the greatest returns in both years (data not shown). Economic values used for these calculations have been previously published (Stover et al, 2001b). However, market conditions providing greater returns for large fruit, negative returns for small fruit, or both, would likely make the economics of greater thinning more favorable.

In both years, return bloom was adequate even in nonthinned trees, producing full commercial crops. While 'Empire' can produce surprisingly large crops in consecutive years, compromising environmental conditions and heavy cropping will often result in a light bloom and low cropload following a year of excessive yields (Stover et al., 2001a). For this reason, many growers thin to achieve consistent crops conducive to good return bloom, rather than simply maximizing crop value within a given year. The multi-step approach of NAA + CB at PF followed by Accel ${ }^{\mathrm{TM}}+\mathrm{CB}$ at 10-mm KFD on 'Empire' appears promising from this study, especially where trees are difficult to thin or inclined to excessivecropping. However, to maximize its usefulness, a consistent method must be developed for assessing effectiveness of preceeding thinning treatments. Having identified the potential of multi-step thinning strategies, further work is needed to assess the long-term cumu- lative value of using such an approach compared with more conventional single thinner applications.

\section{Literature Cited}

Elfving, D.C. and R.A. Cline. 1993. Benzyladenine and other chemicals for thinning 'Empire' apple trees. J. Amer. Soc. Hort. Sci. 118:593-598.

Forshey, C.G. 1986. Chemical fruit thinning of apples. New York Food and Life Sciences Bul. 116:1-7.

Greene, D.W. 1993. A review of the use of benzyladenine (BA) as a chemical thinner for apples. Acta. Hort. 325:231-236.

Greene, D.W., W.R. Autio, J.A Erf, and Z.Y. Mao. 1992. Mode of action of benzyladenine when used as a chemical thinner on apples. J. Amer. Soc. Hort. Sci. 117:775-779.

Greene, D.W., W.R Autio, P. Miller. 1990. Thinning activity of benzyladenine on several apple cultivars. J. Amer. Soc. Hort. Sci. 115:394400.

Leuty, S.J. 1973. Identification of maximum sensitivity of developing apple fruits to naphthaleneacetic acid. J. Amer. Soc. Hort. Sci. 98:247-252

McLaughlin, J.M., and D.W. Greene. 1984. Effects of BA, $\mathrm{GA}_{4+7}$, and daminozide on fruit set, fruit quality, vegetative growth, flower initiation and flower quality of 'Golden Delicious' apples. J. Amer. Soc. Hort. Sci. 109:34-39.

Robinson, T. and A. Lakso. 1991. Thinning strategies to improve 'Empire' apple fruit size. Proc. N.Y. State Hort. Soc. 136:219-225.

Robinson, T., A. Lakso, E. Stover, and S. Hoying. 1998. Practical apple thinning programs for New York. New York Fruit Quart. 6(10):1418.

Stover, E., M. Fargione, R. Risio, X. Yang, and T. Robinson. 2001a. Fruit weight, cropload, and return bloom of 'Empire' apple following thinning with 6-benzyladenine and NAA at several phenological stages HortScience 36:10771081.

Stover, E., F. Wirth, and T. Robinson. 2001b. A method for assessing the relationship between cropload and crop value following fruit thinning. HortScience 36:157-161.

Westwood, M.N. 1967. Cell size, cell number, and fruit density of apples as related to fruit size, position in cluster, and thinning method. Proc. Amer. Soc. Hort. Sci. 91:51-62.

Williams, M.W. and L.J. Edgerton. 1981. Fruit thinning of apples and pears with chemicals. USDA Agr. Info. Bul.

Williams, M.W., S.A. Bound, J. Hughes and S. Tustin. 1995. Endothall: A blossom thinner for apples. HortTechnology 5:257-259.

Wismer, P.T., J.T.A. Proctor, and D.C. Elfving. 1995. Benzyladenine affects cell division and cell size during apple fruit thinning. J. Amer. Soc. Hort. Sci. 120:802-807. 